\title{
Aktualne tendencje w wyborze formy kształcenia uczniów z uszkodzonym słuchem w obecnym systemie oświatowym w Polsce
}

\begin{abstract}
Magdalena Olempska-Wysocka, Aktualne tendencje w wyborze formy kształcenia uczniów z uszkodzonym stuchem w obecnym systemie oświatowym w Polsce [Current tendencies in choosing the form of education of students with hearing impairment in the current educational system in Poland]. Interdyscyplinarne Konteksty Pedagogiki Specjalnej, nr 18, Poznań 2017. Pp. 93-114. Adam Mickiewicz University Press. ISSN 2300-391X
\end{abstract}

The aim of this article is to present changes in the education of deaf and hard of hearing persons over the last 7 years. The trends in the education of children with hearing impairment clearly point to the departure from special forms of education in favour of public education and integration. These changes, however, are a challenge for both teachers, parents and students with hearing impairment.

KEY WORDS: hard of hearing student, deaf student, education of students with hearing impairment

\section{Wprowadzenie}

Rozwój techniki oraz upowszechnienie aparatów słuchowych, implantów ślimakowych, a przede wszystkim powszechność wykonywania przesiewowych badań słuchu spowodowało, że współ- 
cześnie w surdopedagogice stosuje się klasyfikację funkcjonalną, która wyróżnia dwie grupy dzieci z uszkodzonym narządem słuchu. Należą do nich dzieci niesłyszące i słabosłyszące. Dzieci niesłyszące - to dzieci, które mają uszkodzony słuch w takim stopniu, że uniemożliwia im to odbieranie dźwięków mowy w sposób naturalny - za pomocą słuchu. Cechą charakterystyczną tej grupy dzieci jest niemożność opanowania mowy werbalnej drogą naturalną (poprzez naśladownictwo). Druga grupa - dzieci słabosłyszące (niedosłyszące) - to dzieci z uszkodzonym słuchem w takim stopniu, który ogranicza im odbiór mowy drogą słuchową; dziecko słabosłyszące może opanować mowę werbalną drogą naturalną - za pośrednictwem słuchu1. Kazimiera Krakowiak podkreśla także, że nowe uwarunkowania $\mathrm{w}$ surdopedagogice spowodowane są m.in.: zmianami w dziedzinie wiedzy medycznej, osiągnięciami neurolingwistyki i psycholingwistyki rozwojowej, rozwojem teorii i praktyki logopedycznej oraz nowych metod wychowania językowego, powstaniem nowej filologicznej wiedzy o jezzykach migowych². W przypadku dzieci z uszkodzonym słuchem kluczowe jest także jednoczesne uruchomienie badań przesiewowych i sieci instytucji wczesnego wspomagania rozwoju ${ }^{3}$.

Zmiany te implikują zupełnie nowe możliwości w zakresie edukacji, wczesnego wspomagania rozwoju dzieci z uszkodzonym słuchem, a także pomocy psychologiczno-pedagogicznej. Ze względu na powyższe należy pamiętać, że specjalne potrzeby edukacyjne, komunikacyjne dzieci z uszkodzonym słuchem zmieniły się na przestrzeni 20-30 lat i wymagają stosowania innych rozwiązań systemowych.

1 B. Szczepankowski, Niestyszacy - głusi - głuchoniemi, WSiP, Warszawa 1998.

2 K. Krakowiak, Propozycje zmian systemowych w zakresie ksztatcenia dzieci i mtodzieży ze specjalnymi potrzebami edukacyjnymi spowodowanymi przez uszkodzenia stuchu (niestyszących, słabostyszących, niedostyszaccych), „Człowiek - Niepełnosprawność Społeczeństwo" 2016, nr 2(32).

${ }^{3}$ D. Podgórska-Jachnik, Zmiany we wspótczesnej edukacji osób niestyszacych w Polsce w kontekście wybranych rozwiązań polityki oświatowej, „Niepełnosprawność. Dyskursy Pedagogiki Specjalnej" 2016, nr 22, s. 132-152. 


\section{Orzecznictwo, procedura kwalifikacji do formy kształcenia}

Uczniowie z uszkodzonym słuchem mają możliwość kształcenia w szkołach ogólnodostępnych, w szkołach integracyjnych lub z oddziałami integracyjnymi oraz $\mathrm{w}$ szkołach specjalnych. Zgodnie z Rozporządzeniem Ministra Edukacji Narodowej z dnia 18 września 2008 r. w sprawie orzeczeń i opinii wydawanych przez zespoły orzekające działające $\mathrm{w}$ publicznych poradniach psychologicznopedagogicznych, a także z Rozporządzeniem Ministra Edukacji Narodowej z dnia 1 lutego 2013 r. w sprawie szczegółowych zasad działania publicznych poradni psychologiczno-pedagogicznych, $\mathrm{w}$ tym publicznych poradni specjalistycznych wraz z rozporządzeniami zmieniającymi ${ }^{4}$ orzeczenia o potrzebie kształcenia specjalnego, m.in. dla dzieci z uszkodzonym słuchem (słabosłyszących i niesłyszących), wydawane są przez zespoły orzekające organizowane $\mathrm{w}$ publicznych poradniach psychologiczno-pedagogicznych ${ }^{5}$. Zespół orzekający jest powoływany przez dyrektora poradni. W jego skład wchodzi: dyrektor poradni lub osoba przez niego upoważniona, psycholog, pedagog, lekarz, logopeda, którzy opracowują odpowiednie diagnozy ${ }^{6}$.

Na wniosek wnioskodawców ${ }^{7}$ po analizie zebranej dokumentacji medycznej dostarczonej przez nich i na podstawie specjalistycz-

${ }^{4}$ Rozporządzenie Ministra Edukacji Narodowej z dnia 25 sierpnia 2017 r. zmieniające rozporządzenie $\mathrm{w}$ sprawie szczegółowych zasad działania publicznych poradni psychologiczno-pedagogicznych, w tym publicznych poradni specjalistycznych.

${ }^{5}$ Zgodnie z rozporządzeniem, orzeczenia o potrzebie kształcenia specjalnego oraz orzeczenia o potrzebie indywidualnego nauczania dzieci niewidomych i słabowidzących, dzieci niesłyszących i słabosłyszących oraz dzieci z autyzmem i ZA wydają zespoły działające $\mathrm{w}$ poradniach wskazanych przez kuratora oświaty, za zgodą organu prowadzącego.

${ }^{6} \mathrm{~W}$ skład zespołu, zgodnie z rozporządzeniem, mogą także wchodzić inni specjaliści, jeśli ich udział w pracach zespołu jest niezbędny.

7 Rodziców, prawnych opiekunów dziecka. 
nych badań przeprowadzonych w poradni (psychologicznych, pedagogicznych, logopedycznych) na posiedzeniu zespołu orzekającego podejmowana jest decyzja dotycząca kształcenia. Zespół orzeka o potrzebie kształcenia specjalnego lub o braku takiej potrzeby. Wydawane przez poradnie psychologiczno-pedagogiczne orzeczenia o potrzebie kształcenia specjalnego składają się z części diagnostycznej wynikającej z niej części decyzyjnej, zawierają warunki realizacji potrzeb edukacyjnych, formy stymulacji, rewalidacji, terapii, usprawniania, rozwijania potencjalnych możliwości i mocnych stron dziecka, a także inne formy pomocy psychologiczno-pedagogicznej. Należy pamiętać, że orzeczenie zawiera zaleconą formę kształcenia specjalnego dla uczniów z uszkodzonym słuchem: albo w szkole ogólnodostępnej, albo w szkole integracyjnej (lub oddziale integracyjnym), albo w szkole specjalnej (lub oddziale specjalnym). Jednak ostateczną decyzję w jakiej szkole będzie uczyło się dziecko podejmuje rodzic. Na podstawie przedłożonego orzeczenia w organie prowadzącym dziecko zostaje kierowane do zaleconej formy kształcenia ${ }^{8}$. Orzeczenie jest wydawane na okres roku szkolnego, etapu edukacyjnego, okresu kształcenia w danej szkole.

Maria Chróścicka, Wiesława Kodura, Joanna Kosmalowa ${ }^{9}$ na podstawie wieloletniego doświadczenia w diagnostyce oraz moni-

8 Por. I. Chrzanowska, Pedagogika specjalna. Od tradycji do wspótczesności, Oficyna Wydawnicza „Impuls”, Kraków 2015; A. Dziurda-Multan, Edukacja dziecka niestyszącego w szkole ogólnodostępnej wyzwaniem nie tylko dla surdopedagoga, [w:] Kompetencje Pedagoga Specjalnego. Aktualne wyzwana dla teorii i praktyki, red. Z. Palak, A. Bujnowska, Wydawnictwo Uniwersytetu Marii Curie-Skłodowskiej w Lublinie, Lublin 2007; G. Szumski, Prawo rodziców do wyboru formy kształcenia dzieci niepetnosprawnych - mechanizm regulacyjny, wartość samoistna czy ideologia?, „Szkoła Specjalna” 2002, nr 4, s. 266-272; G. Szumski, Teoretyczne implikacje edukacji właczającej, [w:] Uczeń $z$ niepetnosprawnościa w szkole ogólnodostępnej, red. Z. Gajdzica, Humanitas, Sosnowiec 2011.

${ }^{9}$ M. Chróścicka, W. Kodura, J. Kosmalowa, Uwarunkowania decyzji o wyborze szkoty dla dziecka $z$ wada stuchu, [w:] Standardy postępowania diagnostyczno-orzekajacorehabilitacyjnego wobec dzieci i młodzieży. Poradnik dla pracowników pedagogicznych poradni psychologiczno-pedagogicznych oraz nauczycieli szkót, Ministerstwo Edukacji Narodowej i Sportu, Warszawa 2005. 
torowaniu efektów w edukacji szkolnej dzieci z uszkodzonym słuchem opracowały schemat kwalifikacji dziecka do odpowiedniej formy kształcenia. Jeżeli dziecko z wadą słuchu uzyskuje wyniki powyżej przeciętnej w pełnej skali (słownej i bezsłownej) WISC-R ${ }^{10}$, komunikuje się z otoczeniem za pomocą mowy werbalnej, ma opanowane w podstawowym stopniu techniki szkolne, a jego rodzice/opiekunowie z nim pracują, można wtedy rokować pomyślnie o realizacji programu szkoły ogólnodostępnej. Istotne jest $\mathrm{w}$ tym przypadku również to, aby nauczyciel pracujący z uczniem rozumiał złożoność wady słuchu. Jeśli dziecko z uszkodzonym słuchem osiągnęło wyniki na poziomie powyżej przeciętnym, ale tylko w skali bezsłownej, komunikuje się za pomocą mowy werbalnej, ale w ograniczonym zakresie, ma opanowane w podstawowym zakresie techniki szkolne, a jego rodzice $\mathrm{z}$ nim pracują, można proponować takiemu dziecku realizację obowiązku szkolnego w klasie integracyjnej oraz wnioskować o przygotowanie dla dziecka indywidualnego programu, który będzie dostosowany do jego możliwości. Jeśli natomiast dziecko z uszkodzonym słuchem uzyskuje tylko wyniki przeciętne w badaniach, komunikuje się mową werbalną w bardzo ograniczonym zakresie, słabo ma opanowane techniki szkolne, a rodzice/opiekunowie cały czas pracują z dzieckiem - powinno się wtedy proponować realizację obowiązku szkolnego w szkole dla dzieci z uszkodzonym słuchem. Aby proponowana przez specjalistyczne poradnie psychologiczno-pedagogiczne forma kształcenia była optymalna, należy uwzględnić także: czas diagnozy, okres rehabilitacji słuchu i mowy, korzyści z aparatów słuchowych (czy też implantów ślimakowych), możliwość współpracy z rodzicami w procesie terapii, poziom rozwoju języka, poziom zdolności intelektualnych, opanowanie technik szkolnych, koncentracja uwagi, umiejętność samodzielnej pracy, funkcjonowanie emocjonalno-społeczne ${ }^{11}$.

${ }^{10}$ WISC-R (Wechsler Intelligence Scale for Children) - Skala Inteligencji Wechslera dla Dzieci - wersja zmodyfikowana. Jest to test psychologiczny, służący do pomiaru inteligencji ogólnej.

${ }^{11}$ M. Chróścicka, W. Kodura, J. Kosmalowa, op. cit. 


\section{Możliwości kształcenia}

Zgodnie z ustawą o prawie oświaty ${ }^{12}$, a także odpowiednimi rozporządzeniami ministerialnymi ${ }^{13}$ uczeń, który zostanie objęty kształceniem specjalnym (we wszystkich trzech formach - specjalnej, integracyjnej, ogólnodostępnej), musi mieć odpowiednio dostosowany program wychowania przedszkolnego i program nauczania do jego indywidualnych potrzeb rozwojowych i edukacyjnych oraz możliwości psychofizycznych. Podstawę dostosowania stanowi Indywidualny Program Edukacyjno-Terapeutyczny (IPET), uwzględniający zalecenia do pracy $\mathrm{z}$ dzieckiem, które zostały zawarte w orzeczeniu o potrzebie kształcenia specjalnego. Program zostaje opracowany przez zespół14 na podstawie wielospecjalistycznej oceny poziomu funkcjonowania dziecka lub ucznia, z uwzględnieniem zaleceń zawartych w orzeczeniu o potrzebie kształcenia specjalnego, a także w zależności od potrzeb, we współpracy z poradnią psychologiczno-pedagogiczną, w tym poradnią specjalistyczną. Program zostaje opracowany na okres, na jaki zostało wydane orzeczenie poz. 59).

12 Ustawa z dnia 14 grudnia 2016r - Prawo Oświatowe, (Dz. U. z 2016 r.,

${ }^{13}$ Rozporządzenie Ministra Edukacji Narodowej z dnia 24 lipca 2015 r. w sprawie warunków organizowania kształcenia, wychowania i opieki dla dzieci i młodzieży niepełnosprawnych, niedostosowanych społecznie i zagrożonych niedostosowaniem społecznym (Dz. U. z 2015 r., poz. 1113), Rozporządzenie Ministra Edukacji Narodowej z dnia 28 sierpnia 2017 r. zmieniające rozporządzenie w sprawie warunków organizowania kształcenia, wychowania i opieki dla dzieci i młodzieży niepełnosprawnych, niedostosowanych społecznie i zagrożonych niedostosowaniem społecznym (Dz. U. z 2017 r., poz. 1652) oraz Rozporządzenie Ministra Edukacji Narodowej z dnia 30 kwietnia 2013 r. w sprawie zasad udzielania i organizacji pomocy psychologiczno-pedagogicznej w publicznych przedszkolach, szkołach i placówkach (Dz. U. z 2013 r., poz. 532), Rozporządzenie Ministra Edukacji Narodowej z dnia 28 sierpnia 2017 r. zmieniające rozporządzenie w sprawie zasad udzielania i organizacji pomocy psychologiczno-pedagogicznej $\mathrm{w}$ publicznych przedszkolach, szkołach i placówkach (Dz. U. z 2017 r., poz. 1643).

14 Nauczyciele, wychowawcy grup wychowawczych i specjaliści, prowadzący zajęcia z dzieckiem lub uczniem. 
o potrzebie kształcenia specjalnego, nie dłuższy jednak niż etap edukacyjny. Istotą Programu Edukacyjno-Terapeutycznego jest uwzględnienie zakresu i sposobu dostosowania programu wychowania przedszkolnego oraz wymagań edukacyjnych do indywidualnych potrzeb rozwojowych, edukacyjnych, możliwości psychofizycznych dziecka poprzez zastosowanie odpowiednich metod i form pracy. Program określa także formy i okres udzielania dziec$\mathrm{ku}$ lub uczniowi pomocy psychologiczno-pedagogicznej (wraz z wymiarem godzin), działania wspierające rodziców, zakres współdziałania z innymi placówkami, instytucjami, zakres współpracy nauczycieli i specjalistów z rodzicami dziecka oraz zajęcia rewalidacyjne ${ }^{15}$.

Uwzględniając współczesne tendencje oświatowe, które są coraz częściej obserwowane w realiach istniejących w szkolnej rzeczywistości idei systemu włączającego, jak pisze Iwona Chrzanowska16, należy się spodziewać, że coraz więcej dzieci ze specjalnymi potrzebami edukacyjnymi będzie uczęszczało do klas w szkołach ogólnodostępnych. Obecnie zauważyć także można znaczny wzrost liczby dzieci z uszkodzonym słuchem kształconych w szkolnictwie ogólnodostępnym i integracyjnym. Spowodowany jest on zmianami w przepisach oświatowych ${ }^{17}$, większą świadomością rodziców odnośnie do możliwości kształcenia ich dzieci, ale także niestety co raz większą ich presją do tego, aby dziecko uczęszczało do szkoły ogól-

${ }^{15}$ Zgodnie z rozporządzeniem w przypadku dziecka niesłyszącego mogą to być np. zajęcia nauki języka migowego lub innych alternatywnych metod komunikacji (Rozporządzenie Ministra Edukacji Narodowej z dnia 9 sierpnia 2017 r. w sprawie warunków organizowania kształcenia, wychowania i opieki dla dzieci i młodzieży niepełnosprawnych, niedostosowanych społecznie i zagrożonych niedostosowaniem społecznym).

16 I. Chrzanowska, Poziom wrażliwości edukacyjnej uczniów upośledzonych umystowo w stopniu lekkim jako predykator szans edukacyjnych, [w:] Osoba niepetnosprawna $w$ systemie rehabilitacji, edukacji i wsparcia społecznego, red. C. Kossakowski, A. Krause, A. Żyta, Wydawnictwo Uniwersytetu Warmińsko-Mazurskiego, Olsztyn 2007.

17 Ustawa o systemie oświaty MEN z dnia 7 września 1991 r. i 1993 z późniejszymi zmianami, Ustawa z dnia 14 grudnia 2016 r. Prawo Oświatowe, (Dz. U. z 2016 r., poz. 59). 
nodostępnej. Jak pisze Jolanta Barańska ${ }^{18}$, tendencja ta wynika również $\mathrm{z}$ postępu $\mathrm{w}$ medycynie ${ }^{19}$ i technice ${ }^{20}$, wzrostu liczby dzieci objętych wczesnym wspomaganiem rozwoju ${ }^{21}$, wzrostu liczby placówek, gdzie dokonywana jest diagnoza audiologiczna, surdopedagogiczna, surdopsychologiczna, surdologopedyczna, a także wzrostu liczby poradni i ośrodków zajmujących się pomocą psychologicznopedagogiczną i wspomaganiem rozwoju dzieci z uszkodzonym słuchem, upowszechnienia wiedzy na temat możliwości rozwojowych uczniów z uszkodzonym słuchem.

Badania Magdaleny Olempskiej22 dotyczące ścieżek edukacyjnych uczniów z uszkodzonym słuchem przeprowadzone na terenie województwa łódzkiego również pokazują tendencję kształcenia dzieci w placówkach ogólnodostępnych i integracyjnych. Badaniami objęto 283 dzieci i młodzieży z uszkodzonym słuchem w tym

18 J. Barańska, Dzieci z uszkodzonym stuchem w nauczaniu integracyjnym, „Szkoła Specjalna" 2003 nr 4, s. 236-239.

${ }^{19}$ W Polsce, Od 2002 r., dzięki Programowi Powszechnych Przesiewowych Badań Słuchu u Noworodków, zostało przebadanych prawie 5000000 dzieci, wyposażono w sprzęt do przeprowadzania badań przesiewowych wszystkie oddziały noworodkowe, stworzono nie tylko system przesiewowych badań (wykonywanych w 416 ośrodkach I stopnia referencyjności), ale również ośrodki II i III stopnia (kolejno 75 i 24 ośrodków), do których kierowane są noworodki z podejrzeniem wad słuchu. W efekcie Programu na dalsze leczenie skierowanych zostało ok. 278955 dzieci z podejrzeniem występowania wady słuchu (źródło: http://www.wosp.org.pl/me dycyna/nasze_programy/badania_sluchu [dostęp 25.06.2017]).

${ }^{20}$ Intensywny rozwój techniki prowadzi do konstruowania coraz to lepszych urządzeń wspomagających słyszenie - aparatów słuchowych, implantów ślimakowych czy też systemu FM, a także dzięki wczesnej diagnostyce mogą być one stosowane już bardzo wcześnie.

${ }^{21} \mathrm{Z}$ danych SIO (Systemu Informacji Oświatowej) wynika, że rokrocznie wzrasta liczba dzieci objętych pomocą psychologiczno-pedagogiczną a także liczba wydawanych opinii o potrzebie wczesnego wspomagania rozwoju. Dane wskazują, że w roku 2008 dzieci objętych WWR było 14021, w 2011 r. - 18320, 2013 r. - 25592 (źródło: http://brpd.gov.pl/sites/default/files/wyst_2014_07_24_men_odp_01.pdf [dostęp 25.06.2017]).

${ }_{22}$ M. Olempska, Ścieżki edukacyjne uczniów z uszkodzonym stuchem, [w:] W kręgu niepetnosprawności - teoretyczne i praktyczne aspekty poszukiwań w pedagogice specjalnej, red. T. Żółkowska, L. Konopska, Wydawnictwo Print Group, Szczecin 2009. 
117 dziewcząt i 166 chłopców, którzy zostali poddani specjalistycznym diagnozom (psychologicznym, pedagogicznym, logopedycznym, lekarskim) na potrzeby zespołów orzekających na terenie województwa łódzkiego. Dokonano analizy dokumentacji23 uczniów, która pozwoliła ustalić, w jakiej formie lub jakich formach kształcenia odbywał się ich proces edukacji. Na etapie wychowania przedszkolnego łatwo zauważyć, że zdecydowana większość dzieci uczęszcza do placówek ogólnodostępnych (135 dzieci) lub integracyjnych (110 dzieci), co może być podyktowane większą dostępnością tych form kształcenia na tym etapie edukacji, bliskością od miejsca zamieszkania, a także samym wyborem rodziców. Do szkół podstawowych ogólnodostępnych trafiają $\mathrm{w}$ większości uczniowie z lekkim (18 dzieci) i umiarkowanym stopniem uszkodzenia słuchu (31 dzieci), do szkół specjalnych dla słabosłyszących - z lekkim, umiarkowanym i znacznym. Natomiast zdecydowana większość uczniów z głębokim uszkodzeniem słuchu uczęszcza do szkół dla niesłyszących. Przeprowadzona analiza formy kształcenia na poziomie gimnazjum pokazuje, że zdecydowana większość uczniów kształci się w szkołach dla dzieci słabosłyszących oraz dla niesłyszących. Jak wynika $\mathrm{z}$ „Raportu o sytuacji osób głuchych w Polsce" 24 , niepokojący jest fakt systematycznego zmniejszania się liczby dzieci w szkołach dla głuchych i niedosłyszących w normie intelektualnej. Jak wskazują autorzy raportu, do tych szkół coraz częściej przychodzą dzieci $\mathrm{z}$ dodatkowymi niepełnosprawnościami $\mathrm{np}$. autyzmem, niepełnosprawnością intelektualną. Powoduje to, że szkoły specjalne posługują się programem nauczania, który nie uwzględnia specyfiki głuchych, a szkoły ogólnodostępne nie są przygotowane do efektywnego kształcenia dzieci z taką niepełnosprawnością i z takimi problemami komunikacyjnymi.

23 Zebrane dane dotyczą lat 2004/05-2008/09, analizie poddano orzeczenia o potrzebie kształcenia specjalnego, protokoły z zespołów orzekających ds. uszkodzeń słuchu w Specjalistycznej Poradni Psychologiczno-Pedagogicznej Doradztwa Zawodowego i dla Dzieci z Wadami Rozwojowymi w Łodzi.

${ }^{24}$ Sytuacja osób głuchych w Polsce. Raport zespołu ds. g/Głuchych przy Rzeczniku Praw Obywatelskich, red. Marek Świdziński, Warszawa 2014. 
Analiza danych ogólnopolskich z Systemu Informacji Oświatowej (SIO) pozwala również zauważyć pewne tendencje dotyczące kształcenia dzieci i młodzieży z wadą słuchu. W przypadku dzieci słabosłyszących ${ }^{25}$ widoczny jest wzrost liczby uczniów w placówkach ogólnodostępnych i integracyjnych - w przedszkolu, szkole podstawowej i gimnazjum. Na przełomie ostatnich siedmiu lat jest on dość wysoki i wynosi odpowiednio: dla przedszkola ogólnodostępnego i integracyjnego o 554 dzieci, szkoły podstawowej o 1350 uczniów, dla gimnazjum 425. Dane liczbowe pozwalają także zauważyć tendencje spadkowe w przypadku szkolnictwa specjalnego - na poziomie przedszkola - o 30 dzieci, szkoły podstawowej specjalnej - o 39, gimnazjum - o 100 uczniów.

Tabela 1. Zestawienie liczby uczniów słabosłyszących w latach szkolnych 2010/20112016/2017

\begin{tabular}{|c|c|c|c|c|c|c|}
\hline \multirow{2}{*}{$\begin{array}{c}\text { Rok } \\
\text { szkolny }\end{array}$} & $\begin{array}{c}\text { Przedszkolu } \\
\text { ogólnodostęp- } \\
\text { nym lub inte- } \\
\text { gracyjnym }\end{array}$ & $\begin{array}{c}\text { Przed- } \\
\text { szkolu } \\
\text { specjal- } \\
\text { nym }\end{array}$ & $\begin{array}{c}\text { SP ogólno- } \\
\text { dostępnej } \\
\text { lub integra- } \\
\text { cyjnej }\end{array}$ & $\begin{array}{c}\text { SP spe- } \\
\text { cjalnej }\end{array}$ & $\begin{array}{c}\text { Gimnazjum } \\
\text { ogólnodostęp- } \\
\text { nym lub inte- } \\
\text { gracyjnym }\end{array}$ & $\begin{array}{c}\text { Gimna- } \\
\text { zjum spe- } \\
\text { cjalnym }\end{array}$ \\
\hline $2010 / 2011$ & 528 & 30 & 2947 & 306 & 1732 & 327 \\
\hline $2011 / 2012$ & 618 & 30 & 3087 & 265 & 1904 & 266 \\
\hline $2012 / 2013$ & 684 & 25 & 3304 & 221 & 1959 & 227 \\
\hline $2013 / 2014$ & 808 & 34 & 3444 & 215 & 1964 & 217 \\
\hline $2014 / 2015$ & 861 & 35 & 3801 & 238 & 2025 & 205 \\
\hline $2015 / 2016$ & 957 & 43 & 4189 & 246 & 2131 & 187 \\
\hline $2016 / 2017$ & 1082 & 60 & 4297 & 267 & 2157 & 227 \\
\hline
\end{tabular}

Źródło: opracowanie własne na podstawie informacji zawartych w Systemie Informacji Oświatowej, http://www.cie.men.gov.pl/index.php/dane-statystyczne/139.html [dostęp: 1.07.2017]

${ }^{25}$ Zgodnie z wytycznymi ustalonymi przez Międzynarodowe Biuro Audiofonologii (BIAP), uczeń słabosłyszący to uczeń z uszkodzeniem słuchu w stopniu lekkim lub umiarkowanym a uczeń niesłyszący to dziecko z uszkodzeniem słuchu w stopniu znacznym lub głębokim. 
Aktualne tendencje w wyborze formy kształcenia uczniów z uszkodzonym słuchem 103

Graficzna prezentacja danych liczbowych pokazująca tendencje dotyczące kształcenia uczniów z lekkim i umiarkowanym uszkodzeniem słuchu, została zaprezentowana na poniższym wykresie 1 .

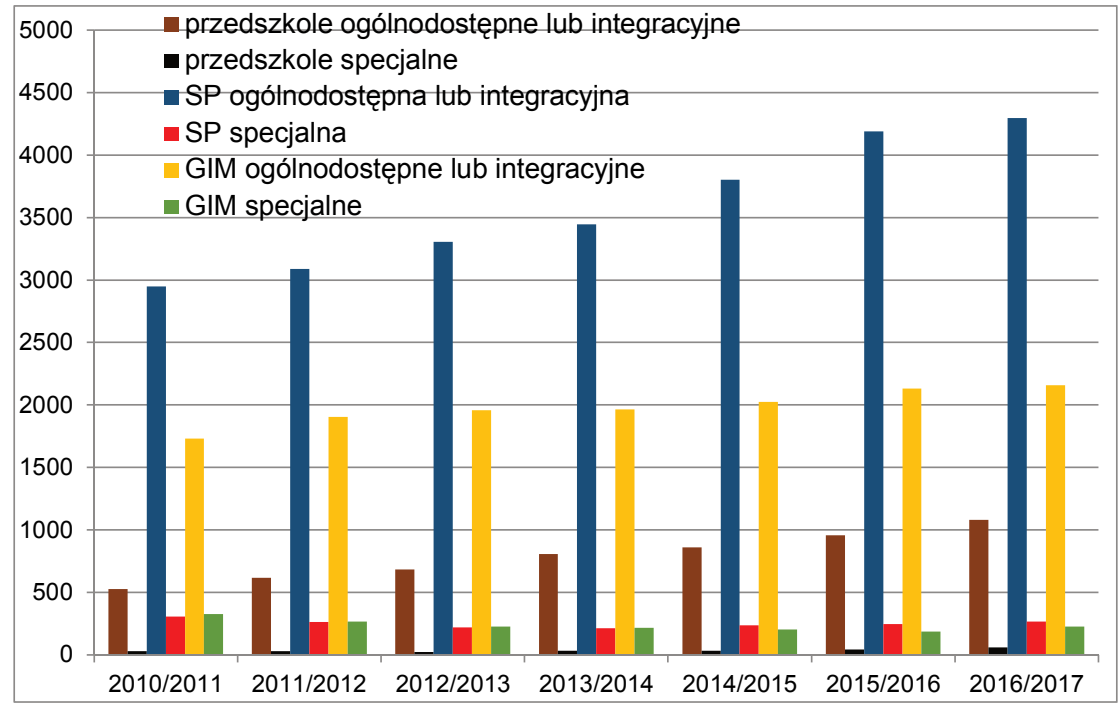

Wykres 1. Zestawienie liczby uczniów słabosłyszących w latach szkolnych 2010/20112016/2017

Źródło: opracowanie własne na podstawie informacji zawartych w Systemie Informacji Oświatowej, http://www.cie.men.gov.pl/index.php/dane-statystyczne/139.html [dostęp: 1.07.2017]

W przypadku dzieci i młodzieży niesłyszących, z uszkodzeniem słuchu w stopniu znacznym i głębokim, tendencje wzrostowe nie są już tak spektakularne. Następuje wzrost liczby dzieci uczęszczających do przedszkola ogólnodostępnego i integracyjnego o 92, ale tendencje wzrostowe są także widoczne $\mathrm{w}$ przypadku przedszkola specjalnego (wzrost liczby dzieci w ciągu ostatnich siedmiu lat wynosi 32). Na poziomie szkoły podstawowej widoczny jest znaczny wzrost liczby kształconych tam dzieci w przypadku szkoły ogólno- 
dostępnej i integracyjnej o 246 uczniów, na niekorzyść szkoły specjalnej (spadek o 210 kształconych w tej formie uczniów). Warto zauważyć, że na poziomie kształcenia gimnazjalnego znaczna większość uczniów niesłyszących uczęszcza do placówek specjalnych. Różnice te są wyraźne i na przełomie ostatnich siedmiu lat nie uległy dużej zmianie ${ }^{26}$.

Tabela 2. Zestawienie liczby uczniów niesłyszących w latach szkolnych 2010/20112016/2017

\begin{tabular}{|c|c|c|c|c|c|c|}
\hline \multirow{2}{*}{$\begin{array}{c}\text { Rok } \\
\text { szkolny }\end{array}$} & $\begin{array}{c}\text { Przedszkolu } \\
\text { ogólnodostęp- } \\
\text { nym lub inte- } \\
\text { gracyjnym }\end{array}$ & $\begin{array}{c}\text { Przed- } \\
\text { szkolu } \\
\text { specjal- } \\
\text { nym }\end{array}$ & $\begin{array}{c}\text { SP ogólnodo- } \\
\text { stępnej lub } \\
\text { integracyjnej }\end{array}$ & $\begin{array}{c}\text { SP spe- } \\
\text { cjalnej }\end{array}$ & $\begin{array}{c}\text { Gimnazjum } \\
\text { ogólnodostęp- } \\
\text { nym lub inte- } \\
\text { gracyjnym }\end{array}$ & $\begin{array}{c}\text { Gimnazjum } \\
\text { specjalnym }\end{array}$ \\
\hline $2010 / 2011$ & 126 & 49 & 168 & 499 & 108 & 380 \\
\hline $2011 / 2012$ & 156 & 59 & 198 & 449 & 107 & 391 \\
\hline $2012 / 2013$ & 174 & 71 & 258 & 436 & 131 & 382 \\
\hline $2013 / 2014$ & 197 & 85 & 310 & 390 & 133 & 366 \\
\hline $2014 / 2015$ & 225 & 89 & 349 & 358 & 143 & 307 \\
\hline $2015 / 2016$ & 188 & 99 & 404 & 319 & 157 & 302 \\
\hline $2016 / 2017$ & 218 & 81 & 414 & 289 & 162 & 229 \\
\hline
\end{tabular}

Źródło: opracowanie własne na podstawie informacji zawartych w Systemie Informacji Oświatowej, http://www.cie.men.gov.pl/index.php/dane-statystyczne/139.html [dostęp: 1.07.2017]

Graficzna prezentacja danych liczbowych pokazująca tendencje dotyczące kształcenia uczniów z znacznym i głębokim uszkodzeniem słuchu, została zaprezentowana na poniższym wykresie 2.

26 Podobne tendencje dotyczące kształcenia dzieci z uszkodzonym słuchem widoczne są w Anglii, Izraelu, Australii i w Stanach Zjednoczonych (Powers S., Inclusion is an attitude not a place: Parts 1 and 2, "Journal of the British Association of Teachers of the Deaf" 1996, 20; Power D., Hyde M., The characteristics and extent of participation of deaf and hard-of-hearing students in regular classes in Australian schools, "Journal of Deaf Studies and Deaf Education" 2002, 7; Zanberg S., Education of children with hearing impairment: Targets and their realization, Israel Ministry of Education, Jerusalem 2005). 


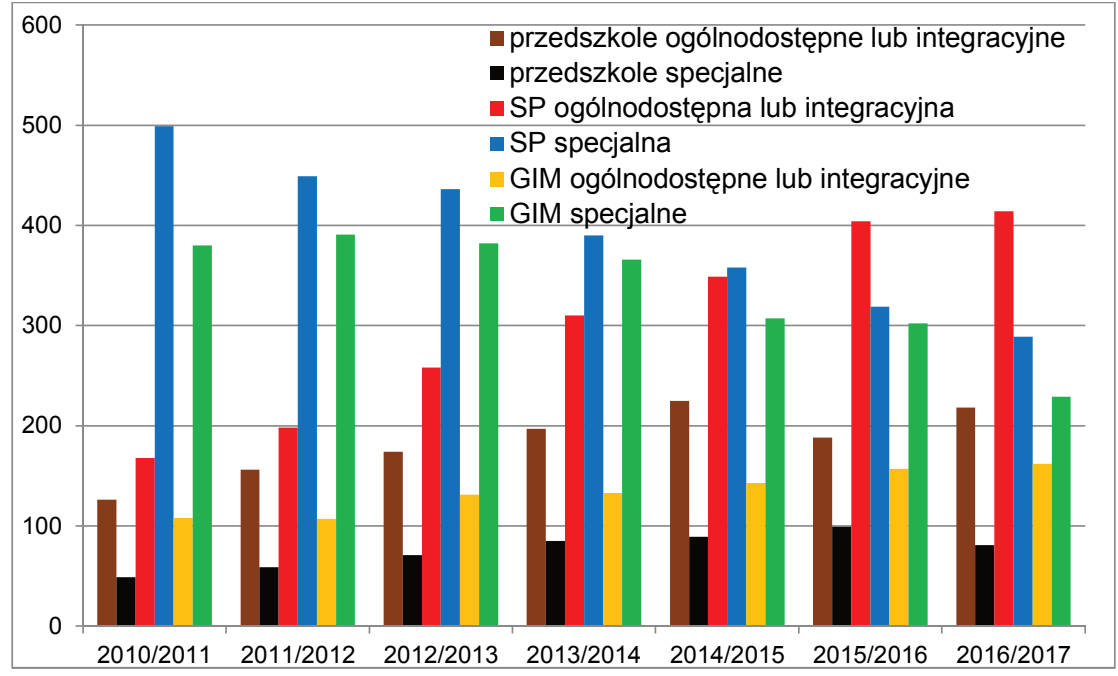

Wykres 2. Zestawienie liczby uczniów niesłyszących w latach szkolnych 2010/20112016/2017

Źródło: opracowanie własne na podstawie informacji zawartych w Systemie Informacji Oświatowej, http://www.cie.men.gov.pl/index.php/dane-statystyczne/139.html [dostęp: 1.07.2017]

Jak podkreśla Małgorzata Kupisiewicz ${ }^{27}$, do niedawna powszechne było przekonanie, że kształcenie dzieci z uszkodzonym słuchem powinno mieć charakter segregacyjny i kompensacyjny. Współcześnie przekonanie to ustępuje miejsca na rzecz kształcenia integracyjnego. Tendencja ta wynika głównie z postulatów, jakie były stawiane przeciwko kształceniu specjalnemu. Dotyczyły one m.in.: nadmiernie opiekuńczej i ochraniającej atmosfery, jaka panowała w specjalnych ośrodkach szkolno-wychowawczych, ograniczeń $\mathrm{w}$ porozumiewaniu się $\mathrm{z}$ rówieśnikami o podobnym (zazwyczaj niskim) poziomie rozwoju językowego ${ }^{28}$, ograniczeń w zakresie

${ }_{27}$ M. Kupisiewicz, Kształcenie dzieci z wada stuchu w systemie integracyjnym jako wyzwanie dla surdopedagogiki, „Szkoła Specjalna” 2006, nr 5, s. 330-337.

28 Jeśli pod uwagę zostanie wzięty fakt, że około $90 \%$ dzieci z uszkodzonym słuchem rodzi się w rodzinach słyszących - problem ten nabiera dużego znaczenia. 
stymulacji do normalnego rozwoju oraz przystosowania społecznego, kształtowanie się izolacyjnych postaw społecznych. Pomimo wielu trudności, na które napotykają uczniowie z uszkodzonym słuchem uczęszczający do szkolnictwa ogólnodostępnego, stwierdza się, że jest to pożądana forma edukacji. Jak podkreśla Grażyna Dryżałowska ${ }^{29}$, szkoły ogólnodostępne-rejonowe są zobligowane do przyjęcia każdego ucznia ze swojego rejonu. W przypadku ucznia $\mathrm{z}$ uszkodzonym słuchem obowiązek wsparcia $\mathrm{w}$ procesie edukacji, zwłaszcza na początku upowszechnienia integracyjnych form edukacji, spoczywał na środowisku rodzinnym, głównie na matkach, które często przejmowały na siebie rolę drugiego nauczyciela. Jak donoszą badania Agnieszki Sakowicz-Boboryko ${ }^{30}$, rodzice dzieci z uszkodzonym słuchem bardzo często napotykali na utrudnienia wynikające m.in.: z braku odpowiednich kompetencji nauczycieli szkół ogólnodostępnych ${ }^{31}$ do pracy z dziećmi niesłyszącymi. Jak pisze autorka, powodzenie ucznia $\mathrm{z}$ uszkodzonym słuchem w szkolnictwie ogólnodostępnym stanowi efekt ciężkiej i żmudnej pracy dziecka oraz rodziców. Jak wskazują badania, do najistotniej-

${ }^{29}$ G. Dryżałowska, Integracja edukacyjna a integracja społeczna. Satysfakcja z życia osób niestyszących, Wydawnictwa Uniwersytetu Warszawskiego, Warszawa 2015.

30 A. Sakowicz-Boboryko, Podmiotowa rola rodziców w edukacji integracyjnej uczniów z wada stuchu, [w:] Wspomaganie rozwoju uczniów ze specjalnymi potrzebami edukacyjnymi, red. D. Osik, A. Wojnarska, Wydawnictwo UMCS, Lublin 2001, A. Sakowicz-Boboryko, Wspieranie rodziców w rehabilitacji dzieci z niepetnosprawnością stuchowa. W kręgu odpowiedzialności, Wydawnictwo Akademickie Żak, Warszawa 2016.

31 W 2009 r. powstał projekt w ramach programu Leonardo da Vinci badający kompetencje nauczycieli pracujących z dziećmi z wadą słuchu w Europie. Badania pokazały, że choć nauczyciele i osoby pracujące z osobami niesłyszącymi były w każdym z krajów partnerskich, to poziom ich kwalifikacji, wiedza i role były bardzo różne. W niektórych krajach, takich jak Dania i Anglia, posiadanie specjalistycznych kwalifikacji jako nauczyciel osób niesłyszących jest obowiązkowe. W innych nie ma takiego wymogu ani nawet nie są jasno określone kryteria wiedzy, umiejętności a także zrozumienie, że nauczyciele, którzy specjalizują się w pracy z dziećmi z wadą słuchu powinni mieć odpowiednie kwalifikacje. Badania pokazały także, że występują znaczne różnice w całej Unii Europejskiej w dostępie do odpowiedniego rodzaju wsparcia, jakie powinno być zapewnione dziecku i jego rodzinie (http:/ / www.batod. org.uk/downloads/leonardo.pdf [dostęp: 14.12.2016]. 
szych czynników powodzenia szkolnego uczniów z uszkodzonym słuchem zalicza się: poziom wykształcenia rodziców, zainteresowanie rodziców sytuacją rewalidacyjną dziecka, poziom wiedzy rodziców na temat niepełnosprawności własnego dziecka, status materialny rodziny, wychowawcza atmosfera w domu rodzinnym.

Już w latach 70. XX w. Kazimierz Kirejczyk ${ }^{32}$ na podstawie badań empirycznych stwierdził, że nauczanie dzieci $z$ wadą słuchu w szkołach ogólnodostępnych daje im możliwość optymalnego rozwoju wraz ze słyszącymi rówieśnikami, wprowadza w normalne środowisko, gdzie nie różnią się niczym od ludzi słyszących - poza wadą słuchu. Jak pisze autor $\mathrm{u}$ podstaw nowoczesnego nauczania i wychowania uczniów z uszkodzonym słuchem powinna leżeć integracja, a nie izolacja. W literaturze przedmiotu istnieje wiele doniesień z badań empirycznych odnoszących się do pozytywnego wpływu integracji na proces kształcenia i wychowania ucznia z wadą słuchu. Urszula Eckert ${ }^{33}$ do istotnych korzyści kształcenia dzieci z uszkodzonym słuchem zalicza:

- zapobieganie rozłące dziecka z domem rodzinnym, środowiskiem jakie jest dziecku najbliższe,

- zapobieganie różnicom pomiędzy dziećmi,

- nawiązywanie kontaktu ze słyszącymi rówieśnikami,

- społeczny rozwój ucznia z uszkodzonym słuchem, rozwój jego umiejętności współdziałania w grupie rówieśniczej,

- motywacja do nauki mowy werbalnej - wzrost zasobu słowno-pojęciowego mowy, rozwój języka dziecka,

- specjalistyczna opieka pedagogiczna (surdopedagogiczna), logopedyczna, psychologiczna, uwzględniająca umiejętności i możliwości dziecka,

- mobilizacja i motywacja rodziców do pracy z dzieckiem.

Współcześnie jednym z najistotniejszych wyzwań, jakie stoją przed pedagogiką specjalną i ogólną, jest realizacja koncepcji wspól-

${ }^{32}$ K. Kirejczyk, Nauczanie głuchych razem ze styszacymi, PWN, Warszawa 1970.

33 U. Eckert, Problemy wczesnego diagnozowania, poradnictwa i ksztatcenia integracyjnego dzieci z wada stuchu, [w:] Dylematy pedagogiki specjalnej, red. A. Rakowska, J. Baran, Wydawnictwo Naukowe Akademii Pedagogicznej, Kraków 2000. 
nego, włączającego kształcenia dzieci z uszkodzonym słuchem ze słyszącymi rówieśnikami. Sukces takiej formy kształcenia uczniów niesłyszących i słabosłyszących zależy od wielu czynników, m.in.: tkwiących w samym dziecku (stopień uszkodzenia słuchu), jego możliwościach, postawach nauczycieli i rówieśników, warunków w jakich odbywa się proces dydaktyczny, przygotowania nauczycieli szkół ogólnodostępnych do pełnienia funkcji rewalidacyjnych ${ }^{34}$. Obecnie szkoły ogólnodostępne staną przed wyzwaniem koniecznego dostosowywania się do ucznia, również takiego, który przejawia niższy poziom językowy niż jego rówieśnicy. Dziecko z uszkodzonym słuchem, rozpoczynające naukę szkolną charakteryzuje się opóźnionym rozwojem językowym. Na stopień tego opóźnienia wpływa wiele czynników m.in.: indywidualne właściwości ucznia, moment rozpoczęcia rehabilitacji logopedycznej itp. Im poziom językowy będzie bardziej odbiegał od norm rozwojowych, tym większe będzie potencjalne zagrożenie niepowodzeniem szkolnym. Sukces szkolny ucznia z uszkodzonym słuchem zależy także od szkoły. Istotne jest, aby stworzyć takie warunki, w których mniej kompetentny uczeń będzie miał okazje do przeżywania sukcesów. Ważne są również warunki, jakie szkoła tworzy do opanowania umiejętności, kompetencji, wiedzy oraz stopień zrozumienia istoty problemów, z jakimi uczeń z uszkodzonym słuchem spotyka się każdego dnia (np. relacje z rówieśnikami, nauczycielami). Wsparcie, jakie zostanie udzielone uczniowi w rozwiązywaniu tych problemów, ma decydujący wpływ na stosunek dziecka do szkoły35.

Kształcenie integracyjne może stwarzać wiele problemów organizacyjnych, merytorycznych oraz technicznych. W przypadku uczniów z uszkodzonym słuchem są to zazwyczaj bariery związane z komunikacją, ale także wynikające $\mathrm{z}$ braku specjalistycznej wiedzy surdopedagogicznej nauczycieli. Problemy te prawdopodobnie stanowią główną przyczynę braku chęci przyjmowania uczniów

${ }^{34}$ M. Kupisiewicz, op. cit., s. 330-337.

${ }^{35}$ G. Dryżałowska, Rozwój językowy dziecka z uszkodzonym stuchem a integracja edukacyjna, model ksztatcenia integracyjnego, Wydawnictwa Uniwersytetu Warszawskiego, Warszawa 2007. 
słabosłyszących i niesłyszących do szkół ogólnodostępnych czy integracyjnych. W efekcie często zdarza się, że uczeń z uszkodzeniem słuchu nie radzi sobie z wymaganiami i warunkami kształcenia w szkole integracyjnej czy ogólnodostępnej. Wówczas - po kilku miesiącach, a niekiedy nawet dopiero po kilku latach - dochodzi do rekwalifikacji zalecanej formy kształcenia i dziecko zostaje przeniesione do szkoły specjalnej ${ }^{36}$. Jednakże podstawową zaletą kształcenia dzieci z wadą słuchu w szkole ogólnodostępnej jest stymulujące środowisko pełnosprawnych rówieśników, które przede wszystkim wpływa na społeczną integrację oraz wspieranie mowy i myślenia uczniów z uszkodzonym słuchem. Taki uczeń w szkole ogólnodostępnej otaczany jest mową werbalną, musi zwracać uwagę na słowa, które są do niego kierowane, ale też sam komunikuje się za pomocą mowy dźwiękowej. Powoduje to, że szybciej opanowuje mowę i potrafi lepiej wykorzystać język do zdobywania nowych wiadomości i umiejętności. Do głównych wad zalicza się natomiast: werbalne metody pracy, brak specjalistycznej wiedzy nauczycieli, którzy nie znają specyfiki rozwoju i uczenia się uczniów z uszkodzonym słuchem oraz dość liczne zespoły klasowe. Te ostatnie stanowią istotne przeszkody $\mathrm{w}$ zaspokajaniu potrzeb dydaktycznych ucznia oraz przyczynę jego niepowodzeń szkolnych. Kształcenie dziecka z uszkodzonym słuchem wymaga silnego zaangażowania rodziców w pracę szkoły. Rodzice nie mogą ograniczać się wyłącznie do pomocy dziecku podczas odrabiania lekcji. Bardzo często odgrywają rolę drugiego pedagoga, pomagają $\mathrm{w}$ nadrabianiu wiadomości szkolnych, wyjaśniają dziecku wiele trudnych dla niego terminów, zwrotów językowych, pomagają w rozumieniu treści, jakie są zawarte w szkolnych podręcznikach ${ }^{37}$. Należy podkreślić, że kwestia wyboru szkoły dla dziecka stanowi trudną i odpowiedzialną decyzję rodziców. Uwzględnianych jest wiele czynników, np. rodzaj szkoły (ogólnodostępna, integracyjna, specjalna), jej lokalizacja, oferta edukacyjna, koszty związane z kształceniem, kompetencje nauczycieli w zakresie możliwości pracy z uczniem, wsparcie

36 B. Szczepankowski, Niestyszaccy - głusi - gtuchoniemi, WSiP, Warszawa 1998.

${ }^{37}$ G. Dryżałowska, Rozwój językowy... 
edukacyjne i terapeutyczne, a także możliwość kontaktu dziecka z rówieśnikami bez niepełnosprawności, ale i z innymi dziećmi z niepełnosprawnością, czy też możliwość korzystania z doświadczeń innych rodziców. W przypadku dzieci z niepełnosprawnością słuchową obecność innych głuchych dzieci jest szczególnie istotna ze względu na to, że daje możliwość komunikacji w języku migowym, choć nie przez wszystkich rodziców jest to postrzegane w kategoriach korzyści, a raczej jako „śmierci dla mowy werbalnej” - co może powodować niczym nieuzasadniony lęk przed kontaktem $\mathrm{z}$ innymi niesłyszącymi i ich naturalnym sposobem komunikacji ${ }^{38}$.

W kontekście dokonywanych wyborów edukacyjnych należy także uwzględnić niezwykle ważne aspekty społeczno-kulturowe, które leżą u ich podstaw. Jak podkreślają autorzy „Raportu o sytuacji osób głuchych w Polsce", warunkiem poprawy sytuacji osób niesłyszących w Polsce jest wprowadzenie edukacji dwujęzycznej. W edukacji niesłyszących idea ta wynika z uznania głuchych za mniejszość językową. Dziecko głuche musi dostać pierwszy język język migowy, a drugim krokiem jest nauczenie go języka większości - języka fonicznego. Jak podkreślają autorzy, znajomość języka migowego jest jedyną drogą umożliwiającą dziecku niesłyszącemu zaspokojenie podstawowych potrzeb (tj. wczesnej komunikacji z rodzicami, rozwijania zdolności poznawczych, zdobywania wiedzy). Doktryna dwujęzyczności funkcjonuje wówczas, gdy otoczenie uzna język migowy za pełnowartościowy język. W Polsce ustawa z dnia 19 sierpnia 2011 r. o języku migowym i innych środkach komunikowania się (Dz. U. z 2011 r. Nr 209, poz. 1243) określa język migowym (PJM) - jako naturalny wizualno-przestrzenny język komunikowania się osób uprawnionych, nie określając jego statusu psycholingwistycznego (czy jest językiem pierwszym czy drugim), choć zabezpiecza podstawowe prawa osób z uszkodzonym słuchem do możliwości korzystania z tłumacza ${ }^{39}$. Jednakże, jak wskazuje

38 D. Podgórska-Jachnik, Uwarunkowania i perspektywy edukacji włączajacej osób z uszkodzonym stuchem, [w:] Edukacja Niestyszacych, red. E. Twardowska, M. Kowalska, Polski Związek Głuchych Oddział Łódzki, Łódź 2011.

${ }^{39}$ D. Podgórska-Jachnik, Zmiany we wspótczesnej edukacji..., s. 132-152. 
raport, szkoły dla niesłyszących nie są przygotowane do kształcenia dwujęzycznego. Przyczyn jest kilka, m.in.: kompetencja językowa nauczyciela (nauczyciele posługują się systemem językowo-migowym, który nie jest językiem naturalnym, jest odmianą migową języka polskiego. Brak kompetencji językowej w zakresie PJM powoduje zablokowanie komunikacji między nauczycielami a dziećmi), metodyka nauczania dzieci (brak programu nauczania PJM, brak podręczników dla dzieci uczących się dwujęzycznie), kwalifikacje nauczycieli40 (brak wymagan wobec nauczycieli, brak odpowiednich przedmiotów w programach studiów), wczesna interwencja (koncentracja jedynie na rozwoju języka fonicznego).

Należy podkreślić także ważność rozwoju tożsamości społeczno-kulturowej Głuchych. Jest on niezwykle istotny, aby osoby z uszkodzonym słuchem: mogły poczuć się wartościowe (pełnowartościowe), mogły poczuć się sprawcze, miały grupę odniesienia, która gwarantuje im możliwość identyfikacji i bezpieczeństwa oraz stanowi dobry punkt wyjścia do kształtowania się tożsamości indywidualnej bez neurotycznego poczucia lęku. W przypadku dzieci i młodzieży szczególnie istotne jest, aby miały wzorce dojrzałych osobowości dorosłych niesłyszących, które pełnią ważną rolę modeli w wychowaniu i w odważnym kreowaniu własnych ścieżek rozwoju ${ }^{41}$.

40 Jak podaje M. Czajkowska-Kisil i A. Klimczewska, Rola języka migowego w ksztattowaniu tożsamości Głuchych w Polsce, [w:] Tożsamość społeczno-kulturowa głuchych, red. E. Woźnicka, Polski Związek Głuchych Oddział Łódzki, Łódź 2007, w szkołach dla głuchych, pracuje niewielu nauczycieli, którzy dobrze znają naturalny język migowy, dlatego nauczyciel ze znajomością PJM cieszy się dużym autorytetem wśród dzieci, ze względu na możliwość naturalnego porozumiewania się. Jak podaje D. Podgórska-Jachnik, Uwarunkowania i perspektywy edukacji włączającej osób z uszkodzonym stuchem, [w:] Edukacja Niestyszacych, red. E. Twardowska, M. Kowalska, Polski Związek Głuchych Oddział Łódzki, Łódź 2011, nauczyciel z uszkodzonym słuchem: rozumie sytuację ucznia niesłyszącego, może być znakomitym wzorcem naturalnego języka migowego, może być wzorcem osobowym podnoszącym poziom aspiracji edukacyjnych niesłyszących uczniów, stwarza okazję do rozwijania wyobrażeń dzieci pełnosprawnych o innym człowieku, odmiennym przez swoją niepełnosprawność; osłabia lęk przed innością i głuchotą.

${ }^{41}$ D. Podgórska-Jachnik, Gtusi wśród styszących - głusi wśród Gtuchych. Problemy integracji społecznej osób z uszkodzonym stuchem w aspekcie tożsamościowym, [w:] Tożsa- 


\section{Podsumowanie}

Możliwości słuchowe i językowe dzieci niesłyszących i słabosłyszących, ulegając zmianie $\mathrm{w}$ ciągu ostatnich lat, wskazują na nową erę $\mathrm{w}$ edukacji i postępowania terapeutycznym $\mathrm{w}$ tej populacji. Dzięki korzyściom, jakie za sobą niosą m.in.: badania przesiewowe słuchu, programy wczesnego wspomagania rozwoju, rozwój technologii, a także założenia edukacji włączającej, zdecydowana większość dzieci z uszkodzonym słuchem na możliwość kształcenia w placówkach ogólnodostępnych i integracyjnych. Nie należy także zapominać o aspektach społeczno-kulturowych i emancypacyjnych w edukacji niesłyszących, a przede wszystkim o języku migowym jako alternatywie dla kształcenia $\mathrm{w}$ języku fonicznym czy też o edukacji dwujęzycznej, za którą silnie optują środowiska niesłyszących w Polsce.

\section{Bibliografia}

Barańska J., Dzieci z uszkodzonym stuchem w nauczaniu integracyjnym, "Szkoła Specjalna" 2003, nr 4.

Chróścicka M., Kodura W., Kosmalowa J., Uwarunkowania decyzji o wyborze szkoły dla dziecka z wada stuchu, [w:] Standardy postępowania diagnostyczno-orzekajacorehabilitacyjnego wobec dzieci i młodzieży. Poradnik dla pracowników pedagogicznych poradni psychologiczno-pedagogicznych oraz nauczycieli szkót, Ministerstwo Edukacji Narodowej i Sportu, Warszawa 2005.

Chrzanowska I., Poziom wrażliwości edukacyjnej uczniów upośledzonych umysłowo w stopniu lekkim jako predykator szans edukacyjnych, [w:] Osoba niepetnosprawna w systemie rehabilitacji, edukacji i wsparcia spotecznego, red. C. Kossakowski, A. Krause, A. Żyta, Wydawnictwo Uniwersytetu Warmińsko-Mazurskiego, Olsztyn 2007.

Chrzanowska I., Pedagogika specjalna. Od tradycji do współczesności, Oficyna Wydawnicza „Impuls”, Kraków 2015.

Czajkowska-Kisil M., Klimczewska A., Rola języka migowego w ksztattowaniu tożsamości Głuchych w Polsce, [w:] Tożsamość społeczno-kulturowa głuchych, red. E. Woźnicka Polski Związek Głuchych Oddział Łódzki, Łódź 2007.

mość społeczno-kulturowa głuchych, red. E. Woźnicka, Polski Związek Głuchych Oddział Łódzki, Łódź 2007. 
Czajkowska-Klisil M., Siepkowska A., Sak M., Edukacja głuchych w Polsce, [w:] Sytuacja głuchych w Polsce. Raport zespotu ds.g/Gtuchych przy Rzeczniku Praw Obywatelskich, red. M. Świdziński, Biuro rzecznika Praw Obywatelskich, Warszawa 2014.

Dryżałowska G., Rozwój językowy dziecka z uszkodzonym stuchem a integracja edukacyjna, model kształcenia integracyjnego, Wydawnictwa Uniwersytetu Warszawskiego, Warszawa 2007.

Dryżałowska G., Integracja edukacyjna a integracja społeczna. Satysfakcja z życia osób niestyszaccych, Wydawnictwa Uniwersytetu Warszawskiego, Warszawa 2015.

Dziurda-Multan A., Edukacja dziecka niestyszącego w szkole ogólnodostępnej wyzwaniem nie tylko dla surdopedagoga, [w:] Kompetencje Pedagoga Specjalnego. Aktualne wyzwana dla teorii i praktyki, red. Z. Palak, A. Bujnowska, Wydawnictwo Uniwersytetu Marii Curie-Skłodowskiej w Lublinie, Lublin 2008.

Eckert U., Problemy wczesnego diagnozowania, poradnictwa $i$ ksztatcenia integracyjnego dzieci z wada stuchu, [w:] Dylematy pedagogiki specjalnej, red. A. Rakowska, J. Baran, Wydawnictwo Naukowe Akademii Pedagogicznej, Kraków 2000.

Kirejczyk K., Nauczanie głuchych razem ze styszacymi, PWN, Warszawa 1970.

Krakowiak K., Propozycje zmian systemowych w zakresie kształcenia dzieci i młodzieży ze specjalnymi potrzebami edukacyjnymi spowodowanymi przez uszkodzenia stuchu (niestyszacych, stabostyszacych, niedostyszacych), „Człowiek - Niepełnosprawność Społeczeństwo" 2016, nr 2(32).

Kupisiewicz M., Ksztatcenie dzieci z wada stuchu w systemie integracyjnym jako wyzwanie dla surdopedagogiki, „Szkoła Specjalna” 2006, nr 5.

Olempska M., Ścieżki edukacyjne uczniów z uszkodzonym stuchem, [w:] W kręgu niepetnosprawności - teoretyczne i praktyczne aspekty poszukiwań w pedagogice specjalnej, red. T. Żółkowska, L. Konopska, Wydawnictwo Print Group, Szczecin 2009.

Podgórska-Jachnik D., Głusi wśród styszących - głusi wśród Gtuchych. Problemy integracji społecznej osób $z$ uszkodzonym stuchem w aspekcie tożsamościowym, [w:] Tożsamość spoteczno-kulturowa głuchych, red. E. Woźnicka, Polski Związek Głuchych Oddział Łódzki, Łódź 2007.

Podgórska-Jachnik D., Uwarunkowania i perspektywy edukacji włączającej osób z uszkodzonym stuchem, [w:] Edukacja Niestyszacych, red. E. Twardowska, M. Kowalska, Polski Związek Głuchych Oddział Łódzki, Łódź 2011.

Podgórska-Jachnik D., Zmiany we wspótczesnej edukacji osób niestyszących w Polsce w kontekście wybranych rozwiązań polityki oświatowej, „Niepełnosprawność. Dyskursy Pedagogiki Specjalnej" 2016, nr 22.

Power D., Hyde M., The characteristics and extent of participation of deaf and hard-ofhearing students in regular classes in Australian schools, "Journal of Deaf Studies and Deaf Education" 2002, 7.

Powers S., Inclusion is an attitude not a place: Parts 1 and 2, "Journal of the British Association of Teachers of the Deaf" 1996, 20. 
Rozporządzenie Ministra Edukacji Narodowej z dnia 1 lutego 2013 r. w sprawie szczegótowych zasad działania publicznych poradni psychologiczno-pedagogicznych, w tym publicznych poradni specjalistycznych.

Rozporządzenie Ministra Edukacji Narodowej z dnia 25 sierpnia 2017 r. zmieniające rozporzadzenie w sprawie szczegótowych zasad dziatania publicznych poradni psychologiczno-pedagogicznych, w tym publicznych poradni specjalistycznych.

Rozporządzenie Ministra Edukacji Narodowej z dnia 18 września 2008 r. w sprawie orzeczeń $i$ opinii wydawanych przez zespoty orzekajace działające $w$ publicznych poradniach psychologiczno-pedagogicznych.

Sakowicz-Boboryko A., Podmiotowa rola rodziców w edukacji integracyjnej uczniów $z$ wada stuchu, [w:] Wspomaganie rozwoju uczniów ze specjalnymi potrzebami edukacyjnymi, Wydawnictwo, red. D. Osik, A. Wojnarska, UMCS, Lublin 2001.

Sakowicz-Boboryko A., Wspieranie rodziców w rehabilitacji dzieci z niepetnosprawnościq stuchowa. W kręgu odpowiedzialności, Wydawnictwo Akademickie Żak, Warszawa 2016.

Szczepankowski B., Niestyszący - głusi - głuchoniemi, WSiP, Warszawa 1998.

Szumski G., Prawo rodziców do wyboru formy kształcenia dzieci niepetnosprawnych mechanizm regulacyjny, wartość samoistna czy ideologia?, „Szkoła Specjalna” 2004, nr 4.

Szumski G., Teoretyczne implikacje edukacji właczającej, [w:] Uczeń z niepetnosprawnościa w szkole ogólnodostępnej, red. Z. Gajdzica, Humanitas, Sosnowiec 2011.

Świdziński M. (red.) Edukacja głuchych w Polsce, [w:] Sytuacja głuchych w Polsce. Raport zespotu ds.g/Gtuchych przy Rzeczniku Praw Obywatelskich, Biuro Rzecznika Praw Obywatelskich, Warszawa.

Ustawa o Prawie Oświaty. Ustawa z dnia 14 grudnia 2016r. (Dz. U. 2017 poz. 59).

Ustawa z dnia 19 sierpnia 2011r o języku migowym i innych środkach komunikowania się (Dz.U. z 2011 r. Nr 209, poz. 1243).

Zandberg S., Education of children with hearing impairment: Targets and their realization, Israel Ministry of Education, Jerusalem 2005.

\section{Źródła internetowe}

http://dera.ioe.ac.uk/9263/1/179_2.pdf [dostęp: 14.12.2016].

http:// www.cie.men.gov.pl/index.php/dane-statystyczne/139.html [dostęp: 1.07. 2017].

http://www.wosp.org.pl/medycyna/nasze_programy/badania_sluchu [dostęp: 25.06. 2017].

http://brpd.gov.pl/sites/default/files/wyst_2014_07_24_men_odp_01.pdf [dostęp: 25.06.2017]. 